\title{
都市緑地における変形菌（真性粘菌）の環境指標生物 としての可能性
}

\author{
Possibility of Myxomycetes as a Bio-Indicator in Urban Green
}

岩田 樹* 鈴木 雅和**

\section{Tatsuki IWATA Masakazu SUZUKI}

\begin{abstract}
The myxomycetes are eulcaryotic unicellular organism. They live in forest floor and feed on micro-organisms such as bacteria, molds, algae and protozoa that inhabit soil, fallen leaves or rotten wood. They make spores and spores are scattered from a fruit body by the wind. When a spore falls in a suitable place for germination, its spore buds and grows. This study aims to develop how to use the myxomycetes as a bio-indicator showed the quality of the urban green environment.

The results showed that 222 kinds of the myxomycetes occurred in 35 urban green in Tokyo. For this reason, it reveals that a number of the myxomycetes live in narrow or isolated urban green. Twelve kinds of the myxomycetes were found in investigation at Showa Memorial Park. The myxomycetes lives in the secondary forest covered with fallen leaves and rotten wood, but we couldn't find them in the forest which ground is hard or grassed down.

According to the results derived in our study and other reference, it needs study to put the myxomycetes as bio-indicator to practical use, example observations of life and case of environmental education or museum exhibit about the myxomycetes. However, we appreciate the myxomycetes as new bio-indicator of urban green environment because of the advantage that if there is a suitable place for living, the myxomycetes can live in urban green because spores of the myxomycetes are scattered by the wind.
\end{abstract}

Keywords: Myxomycetes, bio-indicator, urban green, ability of distributed diffusion キーワード : 変形菌, 環境指標生物, 都市緑地, 分布拡散能力

\section{1.はじめに}

変形菌 (Myxomycetes) は粘菌, あるいは細胞性粘菌と区別 するために, 真性粘菌とも呼ばれている。日本において社会的に は, 南方熊楠がキャラメル箱に標本を入れて昭和天皇に献上した というエピソードによって知られている。生物界分類における変 形菌の地位はこれまで何度も変更されており, 植物・動物の二界 説においては, 植物学者は植物として, 動物学者は動物として扱っ た ${ }^{1)}$ 。Whittaker の生物五界説（動物界・植物界・菌界・プロチ ス夕界・モネラ界）に执いては，動物界・植物界・菌界に入らな い単細胞の真核生物としてプロチス夕界 (Protista) に入れられ ている ${ }^{2)}$ 。最新の Cavalier-Smith の八界説（動物・植物・原生 動物・クロミスタ・菌・アーケゾア・真正細菌・古細菌）によれ ば，変形菌は原生動物界（Protozoa）に入れられている2)。

変形菌は，ミトコンドリアと核膜を持つ真核生物で単細胞であ るが，そのライフサイクルは図－1のように示される。胞子の状 態からスタートすれば，それが発芽してアメーバ状細胞になると 運動能力を持ち, 主として地中でバクテリアを捕食する。単相 （n）で分裂により増殖し, 性別 $(+・-)$ が存在する。アメーバ状 細胞は水分が多い場所では鞭毛細胞になり, 環境が悪い場合はシ ストとして休眠する。この変化は可逆である。+・-のアメーバ 状細胞が接合して接合体 $(2 \mathrm{n})$ を生じた後は，単細胞のまま核だ けが分裂し巨大な多核単細胞の変形体となり, 動物のように運動・ 捕食能力を持つ。環境が悪くなると菌核として休眠し，あるいは 成熟すると地表に這い上がり, 子実体（多くの種は $2 \mathrm{~mm}$ 程度の小 さなキノコ状）を形成する。子実体からは無数の胞子を放出する。 このように, 植物・動物の二元論では理解しにくい生物的特徵を 持っており, 生態的にはまだ未解明の点が多い。著者らは, 国営 昭和記念公園における自然環境調查を 4 年間継続した ${ }^{3-6)}$ 上で, 同公園の花みどり文化センターにおける, 昭和天皇と南方熊楠の 交流に関する展示デザイン ${ }^{7)}$ のため各種取材を行っているうち,
本研究の発想に至った。

\section{2. 研究の目的}

ある土地における環境の豊かさ, 生物の多様性を測る指標とし て, さまざまな生物種群が提案されている ${ }^{899)}$ 。環境指標に生物を 使用する利点は, 自然環境を複合的に把握でき, 人間への影響と して理解しやすく, 高価な機器を必要とせず莫大な経費がかから ないなどがあげられる ${ }^{10)}$ 。一方で, 高度差, 緯度差の大きい日本 の国土において，普遍的に出現する指標種や，逆に都市内の狭く 孤立した土地で利用できる指標種は少ない。

本研究の目的は, 都市緑地管理・保全のための緑地成熟度を示 す環境指標として，変形菌を活用する方法を開発することである。 本論文は，その初歩的な段階であるが，変形菌の既知の生物・生 態的特徵から推定される, 環境指標生物としての意義と可能性に ついて検討し, 今後の研究課題を抽出しょうとするものである。

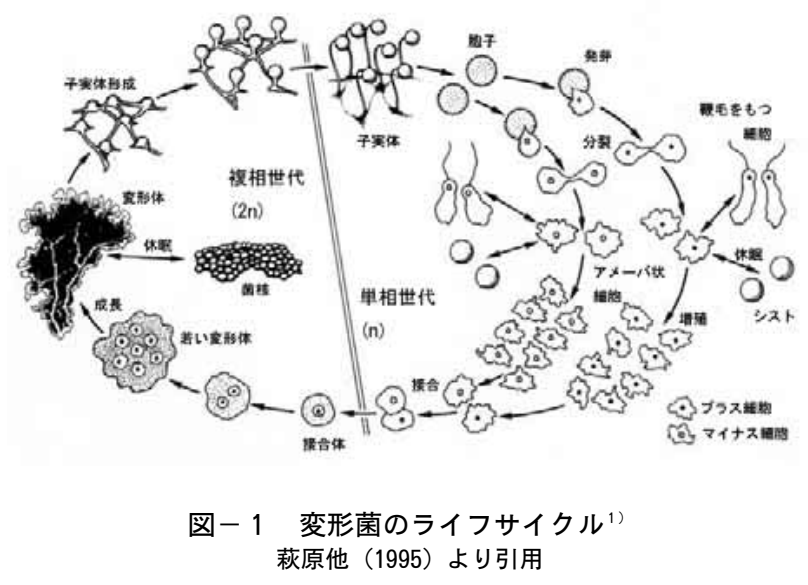

*独立行政法人都市再生機構東日本支社 ${ }^{*}$ 筑波大学大学院人間総合科学研究科 


\section{3. 既往研究と本研究の位置づけ}

変形菌の研究者は少ない。大半の研究は植物分類学の一部とし て行われてきており, 光学顕微鏡レベルにおける形態的分類が基 礎になっている。最近では電子顕微鏡レベルの形態的特徵や分子 生物学的方法による研究も始まっている。しかし, 本研究の目的 に直接関連するような, 変形菌の地理的分布・生態的役割などに 関する研究は, 網羅的かつ連続的な研究蓄積が少なく, 推測の域 を出ていない。変形菌を環境指標として用いる試みは始まったば かりで, 論文報告は見当たらない。一定の緑地空間において変形 菌をむ含むような継続的で総合的な生物相調査の事例は少ないが, 特異な例が京都府「いのちの森」で行われている。そこでは, 人 工的に作られた緑地が経年的に成熟してゆく過程において, 変形 菌の種と発生状況も多様になっているという調查結果 ${ }^{11)-14}$ が明ら かにされている。著者らの発想を裏付ける, 先駆的で数少ない事 例である。豊かな自然, つまり生産者である植物, 消費者である 動物, それらの遺骸を分解する菌類が揃っている環境においては, 分解者である菌類を捕食して分解を抑制する働きを推定されてい る変形菌も数多く認められる傾向がある。しかしこの現象を直接 解明しょうとする研究は少ない。環境中の変形菌の動態を解明し ようとする試み ${ }^{15)}$, 変形菌と節足動物の関係を調查した研究 ${ }^{16)}$ は 興味深い。現時点で判明している，変形菌を中心とする生態系マッ プを図ー2に示した。

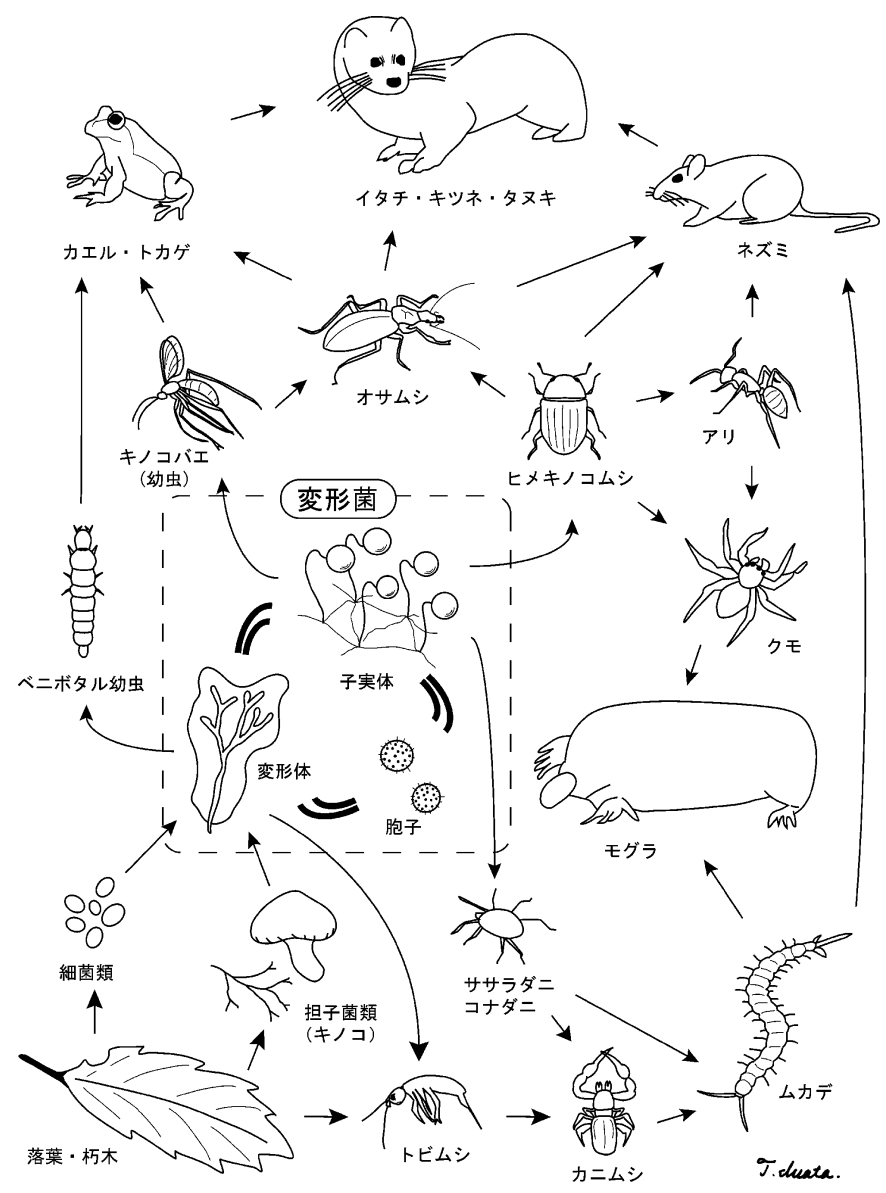

図－２＼cjkstart変形菌を中心とする生態系マップ 青木 $(1973)^{18)}$, 変形菌の既往研究 ${ }^{17)}$ などを基に著者が作成
変形菌の種の同定は，現時点では子実体の状態においてのみ可 能であり, 日本において発見されている種は 500 種に満たない。 そのうち出現頻度の高いものは 55 種程度である ${ }^{1)}$ 。変形菌の胞 子は偏西風・貿易風など大気中を循環し, 地球規模で分散するた め, 温帯・熱帯・亜寒帯に共通する世界的広布種であり, 地域固 有種は存在しない"1)。このことは，日本に限らず，世界のどのよ うな狭い分断された緑地でも，一定の環境が整えば，同一種の変 形菌が発生すると考えられ，世界的に沉用な環境指標として利用 できる可能性を示している。つまり, 他の生物指標は, 地域固有 の種や変種の有無, あるいは同一種でも地域差による発現形質の 差で環境の差を指標しようとする視点に立っているが，変形菌に は環境のある種の同一性を指標しうる可能性があることを意味す る。全世界でも 1,000 種に満たないという変形菌の種数の少なさ は，環境を類型的に把握するためには有利に働くであろう。

問題は, どのような環境で変形菌の胞子が発芽し, 子実体を形 成するまでに至るかという生態的条件が解明されていないため, ミクロな環境の質を同定できない点である。しかしながら，マク ロには分解者を捕食できるような物質循環がされている環境にお いて多く変形菌が発生しているという状況証拠から, その存在が 豊かな環境を指標しうると推定しているというのが現段階である。

本研究は変形菌に関する既往知識に基づき, 緑地の評価・管理・ 運営という視点から, 変形菌が緑地の成熟度を指標する可能性を 検討し，成熟度の高い緑地の保全管理手法につなげること，あわ せて, 変形菌に関する知識の獲得が, 多様な生命観・自然観の再 発見につながり, ひいては緑地のもつ環境教育的価值の増大につ ながるという視点で行うものである。

\section{4. 調查の方法と結果}

変形菌の環境指標としての可能性を検討するために，1)都内の 緑地における既往の発生状況を把握したうえで，2）れまで未調 查の大規模公園において緑地環境区分に応じた, 変形菌の発生状 況を調査した。

\section{（1）都内緑地における既往の変形菌発生状況}

変形菌が緑地の環境指標として利用できるためには，まず都市 緑地に定常的に発生・生息していることを確認する必要がある。 そのため, 国立科学博物館植物研究部に所蔵されている変形菌保 管標本データベースの分析を行った。標本は 1905 年から現在ま でに日本全国で採集されたもので，和名・採集年月日・採集者・ 採集場所が記録されている。全 62,946 標本のうち，東京都内の 緑地（公園・社寺・学校・皇居・離宮）で和名と採集場所が判明 している2,934 標本を対象とした。

その結果, 都内において 251 種が採集されており，うち 222 種 の変形菌は 35 の緑地から採集されたことがわかった。表 1 に出 現頻度の高い変形菌の種リストを示した。図 3 に変形菌の発生し た記録のある東京都内の緑地を示す。皇居で 120 種, 目黒自然教 育園で 109 種, 赤坂離宮で 104 種, などが発見種数の多い緑地で ある。これらのことから，胞子を風散布させ分布拡大をする特性 により, 都内の孤立した緑地でも複数の変形菌種が発生している こと, 標本の採集記録から大正時代から現在まで定常的に発生し ていることが確認できた。

ただし, 変形菌が発生している緑地が東部に偏っているのは, これまでに変形菌調査が主に都心で行われ, 西部において調査が 不十分だったことを示しており, 調査の精度と頻度が発見種数と 相関することを示唆している。今後の綿密な調查が期待される。

発生した変形菌の種類としては, ウツボホコリ， ムラサキホコ リ類，ススホコリ，コウツボホコリが 10 地点以上で収集されて いた。これらは主に朽木に発生し，全国で普遍的に発生するいわ ば普通種であった。特にウツボホコリは春から秋にかけて朽木に 
発生する世界広布種である。落葉に発生する種も多く，シロエノ カタホコリ，ホネホコリ，ジクホコリが採集されていた。

これらのことから都市緑地内の朽木, 落葉の存在が変形菌の生 息に重要であることがわかる。

表一 1 東京都内緑地に高い頻度で発生した変形菌の種

\begin{tabular}{|c|c|c|c|}
\hline 和名 & 発生基物 & 緑地数 & 標本数 \\
\hline "ウツボホコリ & 朽木 & 13 & 36 \\
\hline オオムラサキホコリ & 朽木 & 12 & 28 \\
\hline ススホコリ & 朽木 & 11 & 28 \\
\hline コウツボホコリ & 朽木, 植物遺体上 & 11 & 22 \\
\hline シロエノカタホコリ & 落葉, わら & 10 & 28 \\
\hline シロウツボホコリ & 朽木, 生木樹皮上 & 9 & 27 \\
\hline キウツボホコリ & 朽木 & 9 & 24 \\
\hline シロモジホコリ & 朽木, 生木樹皮上 & 9 & 24 \\
\hline ホネホコリ & 落葉 & 9 & 24 \\
\hline シロジクキモジホコリ & 落葉, 朽木 & 9 & 23 \\
\hline ヨリソイヒモホコリ & 朽木, 生木樹皮上 & 9 & 19 \\
\hline ツノホコリ & 朽木, 生木樹皮上 & 9 & 15 \\
\hline マンジュウドロホコリ & 朽木 & 9 & 13 \\
\hline ムラサキホコリ & 朽木 & 8 & 25 \\
\hline シロフウセンホコリ & 生木樹皮上 & 8 & 18 \\
\hline アオモジホコリ & 朽木 & 8 & 18 \\
\hline ヤリミダレホコリ & 朽木 & 8 & 18 \\
\hline クモノスホコリ & 朽木 & 8 & 17 \\
\hline マルウツボホコリ & 朽木, 生木樹皮上 & 8 & 13 \\
\hline ヒメカタホコリ & 落葉, わら & 8 & 10 \\
\hline ムシホコリ & 朽木 & 7 & 22 \\
\hline ヘビヌカホコリ & 朽木 & 7 & 19 \\
\hline キノウエホネホコリ & 生木樹皮上 & 7 & 17 \\
\hline クダホコリ & 朽木 & 7 & 15 \\
\hline マメホコリ & 朽木, 生木樹皮上 & 7 & 12 \\
\hline
\end{tabular}

\section{（2）国営昭和記念公園における変形菌調査}

多様な緑地環境を持つ大規模都市公園として，東京都立川市の 国営昭和記念公園をとりあげ, 変形菌の生息調查を行った。国営 昭和記念公園は米軍基地跡に 1980 年より公園建設工事に着手さ れた公園であり, 芝生草地から高茎草地, 湿地, 花木園, 花畑, 雑木林など多椂な緑地があり，すべて人工的に造成されたもので ある。中でも，こもれびの丘は市民の植樹により武蔵野の雑木林 を再生するという目的で造成され，自然度の高い空間を目指し， ボランティアの協力によって管理されている。

変形菌調查は 2006 年 8 月から 11 月にかけて合計 7 回行った。 天候はすべて晴れもしくは曇りで, 雨天の直後の日は避けた。こ れは，子実体が発生し，確認しやすいといわれている条件を考慮 した。変形菌は，植物遺体を分解するバクテリアやカビを食べて 生活しているため, 主に林床の朽木, 落葉などに生息してい $3^{1117}$ 。そのため, 緑地内を踏查し, 緑地内の林床環境を観察し ながら, 変形菌が発生しやすい朽木, 落枝, 落葉だまりを探し, 目視による変形菌の生息の有無を確認した。変形菌を発見したら, その場所の林床環境および発生状況を記録し，標本として採集し た。標本は後日, 変形菌分類学の専門家 ${ }^{1)} に よ る$ 同定を受け, 種 名を確定した。なお，変形菌の分類は Nannenga-Bremekamp $(1991)^{19)}$ の体系により，和名は山本 $(1998)^{20)}$ による。

表一 2 が調査によって国営昭和記念公園で採集された変形菌で ある。 6 科 9 属 12 種を認めた。これらはすべて, 最も変形菌の 揭載種数の多い山本 $(1998)^{200}$ において，普遍的に見られる種で あった。変形菌が見られたエリアは，すべて「こもれびの丘」で あり, 落葉広葉樹を主とする雑木林で落葉が $1 \mathrm{~cm}$ 以上積もり, 湿 気があり, 変形菌の発生に重要な落枝や朽木が放置されていた場 所にあたる。また林床が明るく，草本はあまり生えていない樹林 であった。発見された変形菌の多くは，林床にある朽木，枯枝に みられたが，一部ウッドチップや粗梁罒にもへビヌカホコリが見 られた。

変形菌が発生していた樹林は高さ $10 \mathrm{~m}$ 前後のクヌギが $4-5$ $\mathrm{m}$ 間隔で生育し, 林床にはカタクリなど武蔵野在来の野草が生育 する樹林を目標としており，公園管理センターが年に $1-2$ 回, 8 月に刈高 $5-10 \mathrm{~cm}$ で刈り取りを行う林床管理を行っている。そ

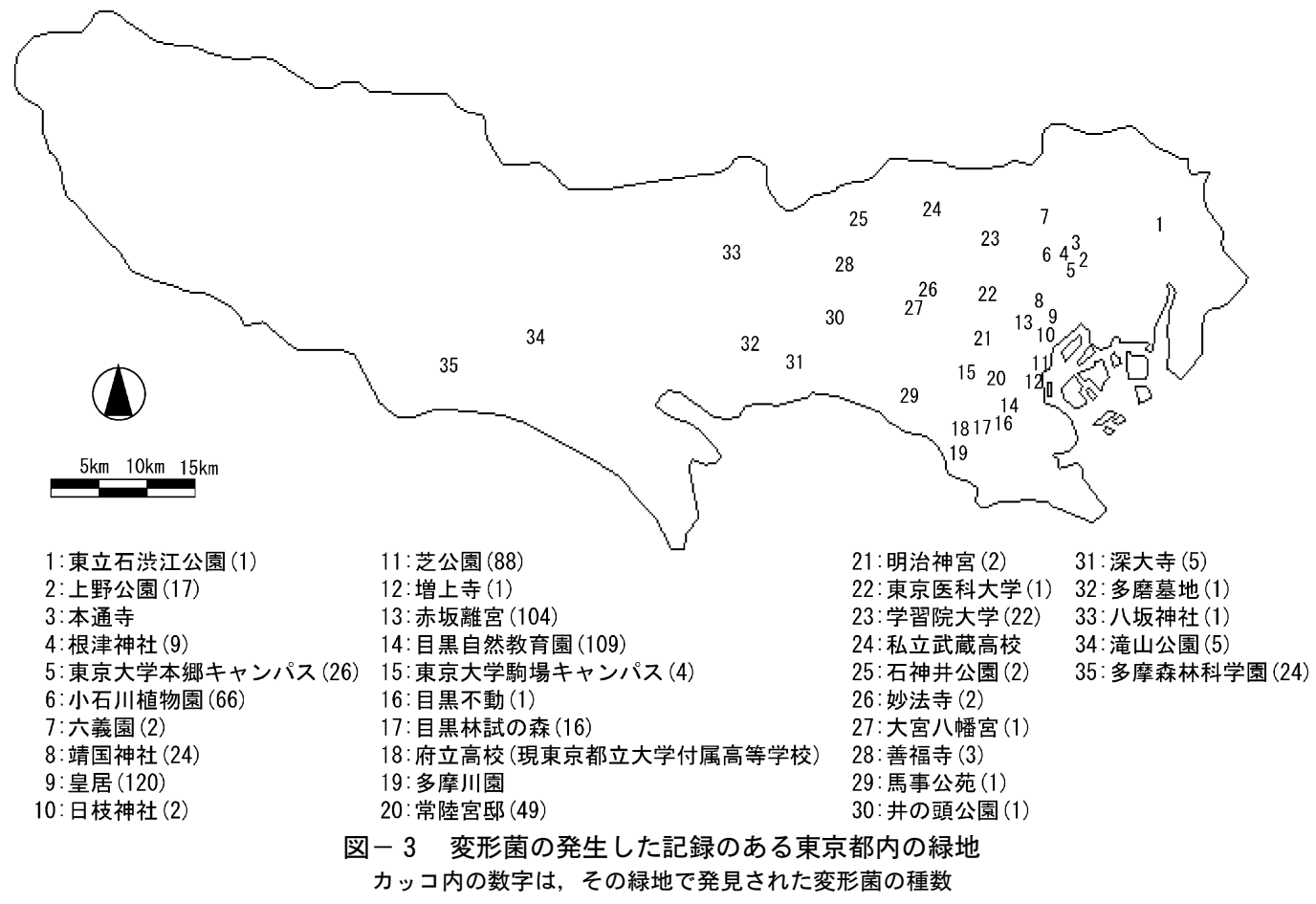


表一－＼cjkstart国営昭和記念公園で発見した変形菌

\begin{tabular}{|c|c|c|c|c|c|c|c|c|c|}
\hline \multirow{2}{*}{ 科 } & \multirow{2}{*}{ 属 } & \multirow{2}{*}{ 種 } & \multicolumn{7}{|c|}{ 発見日（2006 年） } \\
\hline & & & 8.4 & 8.11 & 9.7 & 9.16 & 10.11 & 11.9 & 11.30 \\
\hline \multirow[t]{2}{*}{ アミホコリ } & \multirow[t]{2}{*}{ アミホコリ } & アシナガアミホコリ & & & & 0 & & & \\
\hline & & アミホコリ sp. & $O \triangle$ & & & & & & \\
\hline ウツボホコリ & ウツボホコリ & シロウツボホコリ & & 0 & & & & & \\
\hline クビナガホコリ & クビナガホコリ & クビナガホコリ & & & & 0 & & & \\
\hline ケホコリ & ヌカホコリ & ヘビヌカホコリ & 0 & 0 & & 0 & 0 & 0 & 0 \\
\hline \multirow[t]{4}{*}{ ムラサキホコリ } & エリホコリ & ツヤエリホコリ & & & 0 & O & & & \\
\hline & \multirow[t]{2}{*}{ ムラサキホコリ } & ムラサキホコリ sp. & & & $O \triangle$ & & & & \\
\hline & & ムラサキホコリ sp. II & & & & & & & $\Delta$ \\
\hline & カミノケホコリ & カミノケホコリ sp. & & $O \triangle$ & & & & & \\
\hline \multirow[t]{4}{*}{ モジホコリ } & サカズキホコリ & シロサカズキホコリ & 0 & & & 0 & & & \\
\hline & \multirow[t]{3}{*}{ モジホコリ } & コシアカモジホコリ & & O & & & & & \\
\hline & & モジホコリ sp. & & $O \triangle$ & & & & & \\
\hline & & モジホコリ sp. II & & & & $O \triangle$ & & & \\
\hline
\end{tabular}

科, 属, 種名は, 山本 (1998) に準拠する.

O: 子実体

$\triangle:$ 子実体の残骸

の他に, 目標構成種以外の除去, 樹冠の発達に応じ間伐, 冬季の 落葉掻きを行っている。さらにボランティアが月に数回除草して いる。

一方, 変形菌が認められなかった樹林は, 主要園路沿いの樹林 や, 広場など人の出入りが頻繁にあり, 落葉・落枝, 朽木が無く, 土が固結・乾燥していた場所である。来園者の安全第一という公 園側の運営管理方針により, 落枝・倒木は直ちに撤去され, 利用 性から落葉も掃き清められている。芝やイネ科草本に覆われてい る樹林や，バードサンクチュアリとして人が出入りせず，潅木に 覆われ薄暗い樹林においても変形菌は認められなかった。樹林以 外の草地においても変形菌は認められなかった。もっとも, 変形 菌はシバや単独の生木にも, まれではあるが発生事例があるため, 今後も必ず認められないというわけではない。

国営昭和記念公園における緑地環境区分と変形菌の分布を図一 4 に示した。

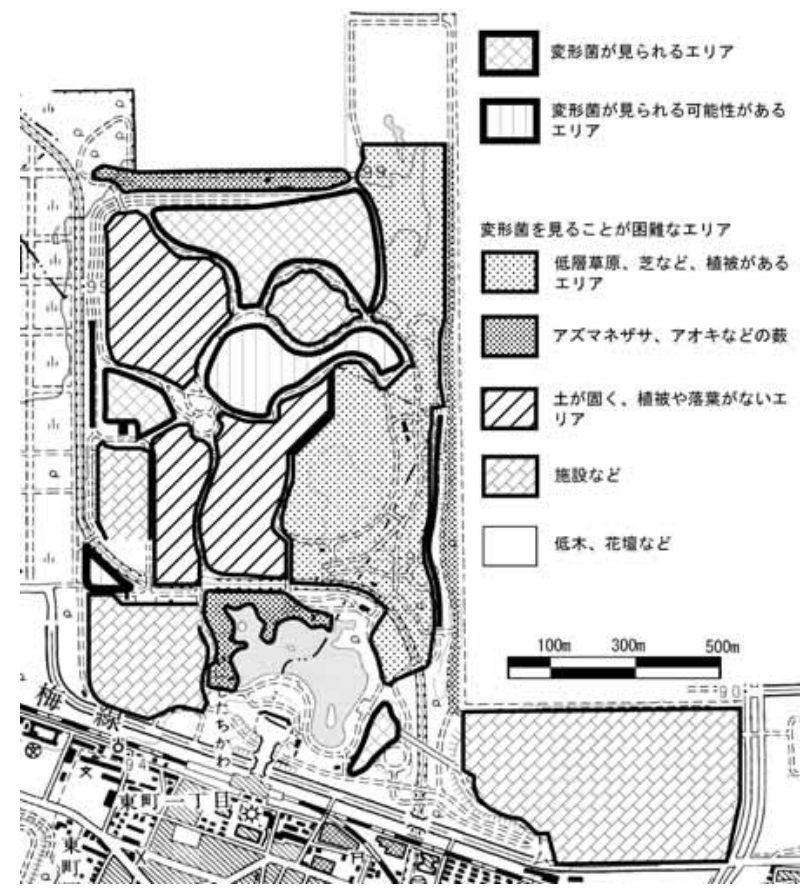

図－４国営昭和記念公園における変形菌分布図
以上，変形菌の既往の生態・生理的知識と屯照らし合わせて考 察すると, 変形菌の存在には, えさとなるバクテリアや菌類（枯 枝，倒木，落葉上に多い）が必要であり，変形体の世代は水分と 暗所を好み, 子実体を形成するためには適度の乾燥と明るさが必 要である。それらの環境がモザイク状に混在あるいは交互に変化 するような環境が必要であり, 倒木が生じるぐらいに成熟し, か つ林床の管理された落葉広葉樹林は, この条件に合い, 変形菌の 存在にとって好適であることが示唆された。このことは, 公園に おける管理体制と管理マニュアルに沿った林床管理と合致してお り，こもれびの丘が目指す環境に向かっていることを変形菌の存 在が示しているともいえよう。

もちろん, すべての緑地がそのような環境を目指す必要は無く, 人間の利用性や安全性, 景観の演出性を考慮した多用なあり方が 求められる。ただ，大規模な公園緑地の場合，変形菌が認められ るようなエリアの存在が緑地の総合的成熟度と生物多様性を増す であろう。

\section{5. 変形菌の環境指標としての可能性に関する考察}

以上の解析結果を踏まえ, 都市緑地で環境指標生物として利用 可能かどうかを松中 $(1979)^{10)}$ ， 日本自然保護協会 $(1994)^{9)}$ を参 考に設定した 15 の基準項目において検討した。その際，都市緑 地に比較的生息しており, 種の同定がしやすく, 環境指標として の研究の蓄積や実績がある, チョウ ${ }^{8212122)}$ とゴミムシ類(3)24225) と比 較することで, 利用可能性を検討した。

なお，ゴミムシ類は，落葉や落枝など林床に生息し，昆虫やミ ミズなどを捕食する肉食性のものや，植物質も摂食する雑食性の ものがいる。チョウは, 飛翔能力があり, 幼虫の食草が決まって いるため, 環境亡密接な結びつきがあるため, それぞれ古くから 環境指標として注目されている。

生息種の地域差, 移動分散能力に関して, チョウの移動能力は 高いが，地域により種構成が異なり，全国規模で利用できる指標 種は数種類しかいない。また, ゴミムシ類の多くは, 後翅が退化

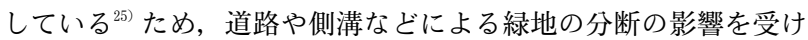
やすい。一度姿を消すと, 外部から侵入し生息することが困難と なり，孤立した都市緑地で環境指標として利用するのは難しい。

一方，変形菌は胞子による風分散をするため，道路などによる 分断は関係なく，孤立した緑地にも発生するため，チョウやゴミ ムシ類などが生息しないような都市緑地でも利用が可能である。 
表 -3 変形菌の環境指標への利用検討

\begin{tabular}{|c|c|c|c|}
\hline 環境指標の基準 & 変形菌 & チョウ & ゴミムシ類 \\
\hline 日本国内に生息する種数 & 453 種 83 変種 22 品種 & 2 上科 5 科 146 属約 245 種 & $\begin{array}{l}182 \text { 属 } 1241 \text { 種（オサムシ科） } \\
3 \text { 属 } 10 \text { 種（ホソクビゴミムシ科） }\end{array}$ \\
\hline $\begin{array}{l}\text { 都市内で利用できる種数 } \\
\text { (変形菌は利用可能性) }\end{array}$ & $\begin{array}{l}\text { 5〜10 種前後（利用可能性のあ } \\
\text { るのは } 40 \text { 種前後） } \\
\text { ウツボホコリ，オオムラリキ } \\
\text { ホコリ, ヘビヌカホコリなど }\end{array}$ & $\begin{array}{l}4 \text { 種 }^{22)} \\
\text { アオスジアゲ八, ナミアゲ八, ツ } \\
\text { マグロヒョウモン, ヤマトシジミ }\end{array}$ & $\begin{array}{l}10 \sim 30 \text { 種 }^{24) 26)} \\
\text { アオオサムシ， ヒメケゴモクムシ， } \\
\text { セアカヒラタゴミムシなど }\end{array}$ \\
\hline $\begin{array}{c}\text { 出現する季節 } \\
\text { (=利用できる季節) }\end{array}$ & $3 \sim 11$ 月 & 5〜10月に多い & 6〜9 月が種数, 個体数ともに多い \\
\hline $\begin{array}{c}\text { 地域による生息種の差異 } \\
\text { 分布拡散能力 }\end{array}$ & $\begin{array}{l}\text { 地域差はない } \\
\text { ・胞子による風散布であるた } \\
\text { め, 世界広布種である。 } \\
\text { ・環境が整えば, 孤立した緑 } \\
\text { 地でも日本全国同じ種が発生 } \\
\text { する。 }\end{array}$ & $\begin{array}{l}\text { 地域差がある } \\
\text { ・地域により生息種が異なるため, } \\
\text { 指標種を普遍化するのが難しい。 } \\
\text { ・緑地から緑地への移動は可能。 }\end{array}$ & $\begin{array}{l}\text { 地域差がある } \\
\text { ・日本国内で広い地理的分布域を } \\
\text { 持つが, 道路や側溝などによる緑 } \\
\text { 地の分断の影響を受けや寸い。 } \\
\text { ・結果, 近縁種が多数存在し, 地 } \\
\text { 域によって生息種が異なるため, } \\
\text { 指標種の普遍化が難しい。 }\end{array}$ \\
\hline $\begin{array}{l}\text { 生息環境の選択性 } \\
\Rightarrow \text { 特定種による環境評価 } \\
\text { の可否 }\end{array}$ & $\begin{array}{l}\text { 種によって発生基物が異なり, } \\
\text { 環境選択性が見られる } \\
\Rightarrow \text { 可能 }\end{array}$ & $\begin{array}{l}\text { ・幼虫は食草が決まっている。 } \\
\text { ・特定の環境と結びつきが強い。 } \\
\Rightarrow \text { 可能 }\end{array}$ & $\begin{array}{l}\text { 環境嗜好性の強い種がいる } \\
\Rightarrow \text { 可能 }\end{array}$ \\
\hline $\begin{array}{l}\text { 種多様性を高める要因 } \\
\Rightarrow \text { 生物が反応する環境要 } \\
\text { 因 }\end{array}$ & $\begin{array}{l}\text { 発生基物の有無, 餌となるバ } \\
\text { クテリア, 湿度, 気温, 光 }\end{array}$ & $\begin{array}{l}\text { 食草の有無, 森林面積率の変化, } \\
\text { 森林から人工被覆への土地利用の } \\
\text { 変化, 空間的なモザイクの多様性 }\end{array}$ & $\begin{array}{l}\text { 地表面の温度や湿度, 日照時間, } \\
\text { 落葉・落枝の有無, 餌, 他種との } \\
\text { 競合 }\end{array}$ \\
\hline 都市緑地での利用 & $\begin{array}{l}\text { ・分布拡散について考える必 } \\
\text { 要がない。 } \\
\text { ・孤立した緑地でも利用可。 }\end{array}$ & 都市で利用できる種数が少ない。 & $\begin{array}{l}\text { 分布拡散に制限があるため, 孤立 } \\
\text { した緑地では利用不可。 }\end{array}$ \\
\hline 既存研究の量 & $\begin{array}{l}\text { ・世界的に調查・研究が少な } \\
\text { い。特に日本では顕著。 } \\
\text { •分類は比較的進んでいるが, } \\
\text { その他の分布はまだ発展途上。 }\end{array}$ & $\begin{array}{l}\text { ・生態, 分類ともにかなり蓄積さ } \\
\text { れている。 } \\
\text { • 環境指標への利用も検討されて } \\
\text { いる。 }\end{array}$ & $\begin{array}{l}\text { • 生態, 分類ともにかなり蓄積さ } \\
\text { れている。 } \\
\text { • 環境指標への利用も検討されて } \\
\text { いる。 }\end{array}$ \\
\hline $\begin{array}{l}\text { 何の環境指標となるか } \\
\text { (変形菌は可能性) }\end{array}$ & $\begin{array}{l}\text { ・都市緑地の自然環境評価お } \\
\text { よび環境分類 } \\
\text { ・林床生態系の豊かさの指標 } \\
\text { ・都市緑地の床保全管理の } \\
\text { 評価 }\end{array}$ & $\begin{array}{l}\text { ・都市および都市近郊の環境を分 } \\
\text { ・地域の自然環境評価を分類 }\end{array}$ & $\begin{array}{l}\text { - 林床管理の種多様性の判断材料 } \\
\text { • 孤立林の経年変化 }\end{array}$ \\
\hline
\end{tabular}

また，世界広布種であるため，生息種に地域差はない。

変形菌の持つ環境指標としての利点は以下のとおりである。

(1) 胞子が風により散布するため, 生息できる環境が整えば, 都 市内の狭く孤立した緑地でも発生する。

(2) 林床の落枝, 落葉, 朽木などに発生する ${ }^{1722728)}$ ため, その存 在が林床保全管理のあり方を反映しやすい（特に, 都市緑地 の中で生物保全上重要な, 適度に管理された落葉広葉樹林に 変形菌が多く発生することから，これを示す指標となる）。

(3) 都市内の緑地でみられる種として 40 種程度, 中でも利用で きるのが $5 \sim 10$ 種と, 種数が限定されている。

(4) 鳥類・哺乳類と異なり, 標本として確実に物的証拠を保存す ることができる。

(5) 運動能力の高い動物と異なり, 植物のように, 限られた範囲 の土地の環境を直接反映していると思われる。

(6) 林床生態系に扔いて, 分解者之高次捕食者をつなぐ一次捕食 者として重要な生態的地位を持っている。

(7) 標本箱がマッチ箱程度であり, 公園緑地において指標生物と して管理しやすい。

(8) 採集に際して, 特別な機具・薬品などを用いることがなく, 非破壊的に調査できる。
(9) 生態・形態が不思議で，拡大すると美しいものもあり，美的 感覚により興味を惹きつける ${ }^{2930)}$ 。

(10)原形質流動など細胞レベルでの観察にも向いた教材で，知的 興味をひきつけやすい。

一方，欠点は以下の之おりである。

(1) 生態的研究をはじめ, 変形菌そのものの研究が初歩的段階で ある。

(2) 子実体の大きさが，ほとんどの種で $2-6 \mathrm{~mm}$ と小さいため, 慣れないと発見しにくい。現地においては 20 倍程度のルー ペが，室内においては，実体顕微鏡が必要である。

(3) 変形菌の種の同定は子実体で可能であり, 変形体での同定は 困難である。同定には生物顕微鏡が必要である。

(4) 子囊菌など変形菌に類似した生物が多く, はじめから一人で 変形菌を探すのは難しく, 指導者のもとで探索する必要があ る。

(5) 植物でも動物でも菌類でもない，新しい生物観が理解されに くい。

チョウ, ゴミムシ類は生態, 分類ともに研究が進んでおり, 実 際環境指標にも応用されている。変形菌は, 分類は比較的進んで はいるが, 生態をはじめ研究の蓄積がまだ少なく, 変形菌の認知 
度も低い。また, 変形体と子実体という大きく異なる姿に変化す る独特の生活環が, 植物, 動物, 菌類と異なり, 理解されにくい 傾向がある。

以上のことから, 生態についての研究や, 変形菌の環境教育や 展示への利用事例を調查するなど, 実用に向けたさらなる研究の 必要があるが, 特に, 胞子を風散布させるため孤立した狭い緑地 でも発生するという利点より, 変形菌が都市緑地における新たな 環境指標生物としての利用価值は高いと判断された。

次に，変形菌が環境指標としての可能性を考察した。

変形菌が林床生態系において一次捕食者という重要な位置にい ることから, 林床生態系の豊かさの指標となることが考えられた。 変形菌が生息することで, その餌となる落葉などの分解者や, 変 形菌を捕食者するキノコバエなよ゙ ${ }^{17311}$ が豊富にいると推測できる。 環境指標には, 生態系における上位捕食者が環境指標生物になる ことが多かったが, 変形菌という生態系の底辺に位置する生物を 環境指標に利用するという新しい視点を提案できた。

また, 緑地内の樹林でも, 落葉や朽木が林床にあり, 湿潤で適 度な管理がされている落葉二次林に变形菌が発生し, 過度の管理 や人の利用がある樹林には変形菌が発生しにくいことがわかった。 これらのことから, 変形菌は, 都市緑地の林床保全管理の評価が できる環境指標などに利用できる可能性が見出された。

都市緑地は, 人間の利用促進または安全性の確保の観点から, 林床では倒木や落葉を排除しきれいにする傾向がある。しかし， 生物多様性を向上させるには, ある程度の粗放的管理が必要であ り, 学術的根拠に基づいて, 両者のバランスを取りながらの公園 管理が求められている。その際, 変形菌の緑地内での分布を調べ ることで, 樹林の環境を的確に把握でき, 管理方針へ反映できる と考えられた。

本研究は, これまで着目されなかった変形菌を対象として, 都 市緑地の保全管理指針に通じる知見を得て, 都市緑地における生 物の環境指標への利用方法を新たに提案しょうとする試みである。 その結果, 変形菌は都市緑地内で林床生態系の豊かさの環境指標, 都市緑地の林床保全管理の評価指標となる可能性があることが判 明した。一方, その他の可能性および利用の実現化に関しては, 昭和記念公園以外の複数の緑地で, 変形菌の生息調査と, その林 床管理を調査し, 変形菌の発生度・発生種を緑地内の環境夕イプ 別に類型化するなど, さらなる調查, 研究, 検討が必要である。

\section{謝辞}

国立科学博物館植物研究部の萩原博光博士には, 変形菌に関す る指導, 採集した変形菌の同定, 博物館に保管している変形菌の データベースを利用させていただいた。国土交通省昭和記念公園 管理事務所及び財団法人公園緑地管理財団昭和管理センターの関 係各位には調査及びヒアリングに協力していただいた。なお，本 研究は, 財団法人都市緑化技術開発機構の助成を受けた。記して 謝意を表する。また, 本研究は文部科学省科学研究費萌芽的研究 No.19658011（研究代表者鈴木雅和）の一部成果による。

\section{引用・参考文献}

1 ）萩原博光・山本幸憲 - 伊沢正名（1995）：日本変形菌類図鑑： 平凡社, $163 \mathrm{pp}$

2 ) 佐橋憲生 (2004): 菌類の森 : 東海大学出版会, $198 \mathrm{pp}$

3 ）日本造園学会: 平成 14 年度国営昭和記念公園生物関連情報 収集・整理検討業務報告書, $110 \mathrm{pp}$

4 ） 日本造園学会: 平成 15 年度国営昭和記念公園生物関連情報 収集・整理検討業務報告書（その 2 ），171pp

5 ）日本造園学会: 平成 16 年度国営昭和記念公園生物関連情報 収集・整理検討業務報告書（その 3 )，116pp
6 ）日本造園学会：平成 17 年度国営昭和記念公園生物関連情報 展示制作・生物生態調查他業務報告書, $179 \mathrm{pp}$

7 ）日本造園学会：平成 18 年度国営昭和記念公園生物関連情報 展示制作・生物生態調查分析他業務報告書, $142 \mathrm{pp}$

8 ) 夏原由博（2000）：都市近郊の環境傾度に沿ったチョウ群集 の変化：ランドスケープ研究 63(5), 515-518

9 ) 日本自然保護協会 (1994)：フィールドガイドシリーズ(3) 指標生物 自然を見るものさし：平凡社, $364 \mathrm{pp}$

10）松中昭一（1979）：図説 環境污染と指標生物：朝倉書店, $198 \mathrm{pp}$

11）小林久泰・松本淳 (1998)：「きのこ」分野調查報告一その 2 : いのちの森 No. 3 報告書, 1998 年度調査報告, 38-40

12）下野義人・岩瀬剛二・小林久泰・田中安代・大薮崇司・川島 聡子・普代貴子（1999）：「きのこ」分野調查報告一その $1-$ : いのちの森 No. 4 報告書, 1999 年度調査報告, 22-37

13）松本淳・小林久泰（1999）：「きのこ」分野調査報告一その 2 変形菌類一：いのちの森 No. 4 報告書, 1999 年度調査 報告, $37-38$

14）松本淳・小林久泰（2000）：「きのこ」分野報告一その 2 変形菌類－：いのちの森 No. 5 報告書, 2000 年度調査報告, 41-42

15）加茂野晃子 - 福井学（2002）：環境中における変形菌 (Myxomycetes) の動態解析に向けた試み：第 18 回日本微 生物生態学会報告

16）杉浦真治・深沢遊・山崎一夫（2002）：変形菌子実体上の節 足動物群集：菌類の繁殖生態に関わる節足動物の機能と生態 研究集会報告

17）山本幸憲（2003）：変形菌の生態概要：高知県の植物 17 , 99-136

18）青木淳一（1973）：土壌動物学 分類・生態・環境との関係 を中心に：北隆館, $814 \mathrm{pp}$

19) Nannenga-Bremekamp (1991) : A Guide to Temperate Myxomycetes: Biopress Ltd, 409pp

20）山本幸憲（1998）：図説日本の変形菌：東洋書林，700pp

21）吉田宗弘（2002）：都市環境指標としてのチョウ類群集の問 題点：環動昆 13(2)，87-92

22）吉田宗弘（2004）：チョウ類群集による都市環境評価のここ ろみ：環動昆 15(3), 179-187

23）石谷正宇（1996）：環境指標としての地表俳徊性ゴミムシ類： 昆虫と自然 31(12)，2-7

24）松本和馬 (2005)：森林総合研究所多摩試験地および東京都 立桜ヶ丘公園のゴミムシ類群集と林床植生：環動昆 16(1), 31-38

25）石谷正宇（1999）：環境指標としてのゴミムシ：インセクタ リゥム $12,18-24$

26）谷脇徹・久野春子・細田浩司（2005）：都市近郊の小規模孤 立林における地表性昆虫類の群集構造の経年变化 : 日本緑化 工学会誌 $30(3), 552-560$

27) G.W.Martin - C.J.Alexopoulos - M.L.Farr (1969): The Genera of Myxomycetes : University of Iowa Press, 561pp

28) Steven L. Stephenson - Henry Stempen (1994): MYXOMYCETES A Handbook of Slime Molds : TIMBER PRESS, 183pp

29）萩原博光・伊沢正名（1983）：森の魔術師たち 変形菌の華 麗な世界：朝日新聞社， $110 \mathrm{pp}$

30）松本淳・伊沢正名（2007）：粘菌一驚くべき生命力の謎一： 誠文堂新光社, $144 \mathrm{pp}$

31) Keller, H.W and D.M.Smith (1978): Dissemination of myxomycetes spores through the feeding activities (ingestion-defecation) of an acrid mite.: Mycologia70, 12391246 